\title{
Strategy for the risk of fall prevention: interventions on global population; specific interventions on selected high risk population
}

M locco

From de Senectute: Age and Health Forum

Catanzaro, Italy. 5-7 December 2009

Many literature studies show that almost one-third of elderly people who never have fallen before, have a fear of falling anyway. This rate increases in people that have fallen before.

Fear plays a very important role in influencing the elderly person, causing a loss of independence in ADL. It's important to evaluate the intensity of this loss to make educative interventions to support elderly people.

A correct clinical evaluation is essential in taking care of elderly people. Pathologies and conditions that could facilitate falls have to be underlined during the clinical evaluation. Moreover, a multi-factorial evaluation of risks is very important in elderly people that have fallen before.

To reduce the incidence of falls in the global population we must improve intervention that includes individual physical exercise programs that aim to increase strength, walking, balance, moves and climbing stairs.

In high risk population it is necessary to add intervention in the house, infrastructure and furniture facilities.

According to some scientific work, an unsafe house increases the risk of fall in $50 \%$. of houses .

Published: 19 May 2010

doi:10.1186/1471-2318-10-S1-L66

Cite this article as: locco: Strategy for the risk of fall prevention:

interventions on global population; specific interventions on selected

high risk population. BMC Geriatrics 2010 10(Suppl 1):L66.
Submit your next manuscript to BioMed Central and take full advantage of:

- Convenient online submission

- Thorough peer review

- No space constraints or color figure charges

- Immediate publication on acceptance

- Inclusion in PubMed, CAS, Scopus and Google Scholar

- Research which is freely available for redistribution

Submit your manuscript at www.biomedcentral.com/submit
C Biomed Central 